\title{
Bioactivity of selected plant-derived essential oils against Zabrotes subfasciatus (Coleoptera: Bruchidae)
}

\author{
Wagner A. Bernardes ${ }^{a}$, Eliane O. Silva ${ }^{b}$, Antônio E.M. Crotti ${ }^{c}$, Edson L.L. Baldin ${ }^{\text {a, * }}$ \\ a Departamento de Proteção Vegetal, Faculdade de Ciências Agronômicas, Universidade Estadual Paulista Júlio de Mesquita Filho, 18610-307, Botucatu, SP, \\ Brazil \\ ${ }^{\text {b }}$ Departamento de Química Orgânica, Instituto de Química, Universidade Federal da Bahia, CEP 40170-115, Salvador, BA, Brazil \\ ${ }^{c}$ Departamento de Química, Faculdade de Filosofia, Ciências e Letras de Ribeirão Preto, Universidade de São Paulo, CEP 14040-900, Ribeirão Preto, SP, Brazil
}

\section{A R T I C L E I N F O}

\section{Article history:}

Received 7 December 2017

Received in revised form

18 February 2018

Accepted 23 February 2018

Available online 8 May 2018

\section{Keywords:}

Phaseolus vulgaris

Repellent activity

Fumigant activity

Essential oil

Stored grain management

\begin{abstract}
A B S T R A C T
The common bean Phaseolus vulgaris L. (Fabaceae) is an important vegetable protein source and constitutes a significant part of the diet in many tropical countries. The Mexican bean weevil Zabrotes subfasciatus (Boheman) (Coleoptera: Bruchidae) is one of the main pests affecting stored beans: it causes extensive qualitative and quantitative grain loss. We investigated the bioactivity of the essential oils extracted from Chenopodium ambrosioides L. (CA-EO), Ocimum gratissimum L. (OG-EO), and Schinus terebinthifolius Raddi (ST-EO) against Z. subfasciatus. After 12-h treatment, CA-EO and OG-EO at $20.0 \mu \mathrm{L} / \mathrm{L}$ of air killed $100 \%$ Z. subfasciatus, whereas ST-EO at $100.0 \mu \mathrm{L} / \mathrm{L}$ of air afforded $100 \%$. subfasciatus mortality after $24 \mathrm{~h}$. CA-EO provided the lowest $24 \mathrm{~h} \mathrm{LD} 50(0.8 \mu \mathrm{L} / \mathrm{L}$ of air $)$ and displayed efficient repellent activity against Z. subfasciatus. Our results demonstrate that CA-EO is a potentially economical and environmentally friendly alternative to manage $Z$. subfasciatus in stored beans.
\end{abstract}

() 2018 Elsevier Ltd. All rights reserved.

\section{Introduction}

The global population is expected to be higher than 8.5 billion in 2025 (Babu et al., 2003), and this situation will clearly demand increased food production. The common bean Phaseolus vulgaris $\mathrm{L}$. is consumed worldwide and constitutes an important calorie and protein source (Lagarda-Diaz et al., 2009). Several research groups have studied post-harvest grain loss (Alonso-Amelot and AvilaNúñez, 2011). When it comes to stored grains, the insect infestation can reduce the grain quantitative and qualitative contents (Madrid et al., 1990). Among the various insects that affect stored grains, the Mexican bean weevil Zabrotes subfasciatus (Boheman) (Coleoptera: Bruchidae) stands out (Costa et al., 2014). Weevil attack diminishes grain weight, alters the grain physical properties, and increases microorganism invasion (Baldin and Lara, 2008).

In this scenario, improved food storage strategies are crucial to mitigate losses and to meet the feeding needs of the growing world population. The battle against stored food infestation generally requires the use of chemical insecticides, which has undesirable consequences such as deleterious effects on the environment and on biodiversity (Moshi and Matoju, 2017). To overcome this issue, natural insecticides based on plant-derived products have been suggested as suitable approaches to weevil management (Jumbo et al., 2014). In this context, essential oils (EOs) have received special attention due to their natural biological functions like fungicidal, bactericidal, and insecticidal activities (Bakkali et al., 2008). These EOs act by disrupting the insect's neurophysiological functions: they target the $\gamma$-aminobutyric acid (GABA) receptors (Priestley et al., 2003) and octopaminergic system (Enan, 2001, 2005), and they inhibit acetylcholinesterase (López and PascualVillalobos, 2010).

Recently, the Chenopodium ambrosioides L., Ocimum gratissimum L., and Schinus terebinthifolius Raddi EOs have been shown to display interesting insecticidal activity against some insect pests (Denloye et al., 2010; Nguemtchouin et al., 2013), but their activities against $Z$. subfasciatus have not been reported yet. In this paper, we investigate the fumigant and repellent potential of the EOs extracted from these plant species against $Z$. subfasciatus.

\footnotetext{
* Corresponding author

E-mail address: elbaldin@fca.unesp.br (E.L.L. Baldin).
} 


\section{Material and methods}

\subsection{Insect colony}

During this study, a Z. subfasciatus colony was maintained in a BOD chamber $\left(25 \pm 2{ }^{\circ} \mathrm{C}, 70 \% \pm 10 \% \mathrm{RH}\right)$ in order to obtain a sufficient number of insects to conduct the proposed bioassays. The insects were placed in clear 1-L glass flasks closed with a screw-on lid. This lid contained a circular opening that held a fine-mesh nylon screen, which allowed internal aeration. Each flask received approximately $0.3 \mathrm{~kg}$ of commercial Carioca bean seeds and approximately 200 unsexed adult insects. The seeds were periodically replaced, and emerging adult insects were used to infest new flasks and to keep the colony.

\subsection{Essential oil extraction and chemical components}

C. ambrosioides (Chenopodiaceae), O. gratissimum (Lamiaceae), and $S$. terebinthifolius (Anacardiaceae) were collected near the city of Patrocínio ( $18^{\circ} 56^{\prime} 35^{\prime \prime}$ S; $46^{\circ} 59^{\prime} 31^{\prime \prime}$ 0; $972 \mathrm{~m}$ ), State of Minas Gerais, Brazil, in March 2011. The plants were identified by Prof. Rosângela de Oliveira Araújo. Voucher specimens (HUFU 61679, HUFU 61682 and HUFU 61673, respectively) were deposited at the Herbarium of the Federal University of Uberlândia, Minas Gerais, Brazil (Herbarium HUFU).

Fresh leaves of each plant species were submitted to hydrodistillation in a Clevenger-type apparatus for $3 \mathrm{~h}$. To this end, $1500 \mathrm{~g}$ of plant material was divided into three $500-\mathrm{g}$ samples, and $500 \mathrm{~mL}$ of distilled water was added to each sample. The EOs were collected manually; traces of water remaining in the oils were removed with anhydrous sodium sulfate, followed by filtration. The EOs were stored in amber bottles and kept in the refrigerator at $4{ }^{\circ} \mathrm{C}$. The C. ambrosioides (CA-EO), O. gratissimum (OG-EO), and S. terebinthifolius (ST-EO) EO yields were calculated from the weight of the leaves and expressed as the average of triplicate analysis.

\subsection{Fumigant toxicity}

The activities of the EOs (CA-EO, OG-EO, and ST-EO) against Z. subfasciatus were evaluated by fumigation. For this purpose, CAEO, OG-EO, ST-EO samples were dissolved in Tween 80. A filter paper was impregnated with eight graded doses of each EO to provide fumigant concentrations of $2.5,5.0,10.0,20.0,40.0,60.0$, 80 , and $100.0 \mu \mathrm{L} / \mathrm{L}$ of air. For the most active EO, CA-EO, the concentration of $1.25 \mu \mathrm{L} / \mathrm{L}$ of air was also tested. The filter papers were attached to the undersurface of the screw cap of a 50-mL glass vial (fumigation chamber). Five adult one-day-old $Z$. subfasciatus couples and $10 \mathrm{~g}$ of beans were transferred to the vials. Five replicates of each treatment and controls were set up, and the percentage adult mortality was recorded $12,24,48$, and $72 \mathrm{~h}$ after treatment. The insects were considered dead when no leg or antennal movements were observed. Tween 80 was used as negative control; the insecticide based on aluminum phosphide (Gastoxin- B $57^{\circledR}$, Bequisa Co, São Vicente, Brazil) was used as positive control at the dose recommended by the manufacturer $\left(2 \mathrm{~g} / \mathrm{m}^{3}\right.$ of air).

\subsection{Repellent activity}

The EO repellent activities were assessed by using the methodology described by Procópio and co-workers (Procópio et al., 2003). The experimental apparatus consisted of five circular plastic containers - the central container was connected to the other four containers by plastic cylinders (12-cm long, 1-cm diameter). Two lateral containers were filled with beans treated with 50,100, and $500 \mu \mathrm{L}$ of one of the EOs/kg of bean. Two other lateral containers (controls) were filled with untreated beans. In the central container, ten one-day-old adult couples were released. The total number of insects per container was recorded after $24 \mathrm{~h}$. Ten replicate assays were carried out for each EO in a completely randomized design.

\subsection{Statistical analysis}

The data obtained from the biological assays (percentage mortality and repellent activity) were submitted to one-way ANOVA. The normality and the homogeneity of the variances were verified through Shapiro-Wilk and Levene tests, respectively (Winer et al., 1991). Differences between treatment means were determined by using Tukey's Studentized (HSD) test (Ogendo et al., 2008). The software SAS was employed (SAS Institute, 2001). To estimate the $\mathrm{LD}_{50}$ values, the relationship between the applied EO concentration and the percent insect mortality was determined by probit (softwares Poloplus Probit and Logit Analysis version 1.0) regression analysis of transformed data. The Abbott formula was used to calculate the control efficiencies (Abbott, 1985).

The repellent activity index (RI) was calculated as proposed by Lin et al. (1990): $R I=2 G /(G+P)$, where $G=$ number of insects in the container with treated beans and $\mathrm{P}=$ number of insects in the container with untreated beans. The classification interval $(\mathrm{CI})$ was calculated by the formula $\mathrm{CI}=1 \pm \mathrm{t}(\mathrm{n}-1 ; \alpha=0.05) \times \mathrm{SD} / \sqrt{ } \mathrm{n}$, where $\mathrm{t}=$ tabulated value, $\mathrm{SD}=$ standard deviation, and $\mathrm{n}=$ number of repetitions. Comparison between the $\mathrm{RI}$ and the $\mathrm{CI}$ values indicated the EO activity: $\mathrm{RI}=\mathrm{CI}$ corresponded to neutral activity, $\mathrm{RI}>\mathrm{CI}$ maximum referred to attraction activity, and $\mathrm{RI}<\mathrm{CI}$ minimum corresponded to repellent activity.

Table 1

CA-EO, OG-EO, and ST-EO fumigant activity (percentage adult mortality) against Z. subfasciatus

\begin{tabular}{llllll}
\hline EO & \multicolumn{5}{l}{ Exposure time } \\
\cline { 2 - 5 } $\begin{array}{l}\text { Tested dose } \\
\text { ( } \mu \text { L/L of air })\end{array}$ & $12 \mathrm{~h}$ & $24 \mathrm{~h}$ & $48 \mathrm{~h}$ & $72 \mathrm{~h}$ \\
\hline CA-EO & 1.25 & $0.0 \pm 0.0 \mathrm{a}$ & $0.0 \pm 0.0 \mathrm{a}$ & $0.0 \pm 0.0 \mathrm{a}$ & $0.0 \pm 0.0 \mathrm{a}$ \\
& 2.5 & $8.2 \pm 0.8 \mathrm{ab}$ & $72.5 \pm 2.1 \mathrm{~b}$ & $100.0 \pm 0.0 \mathrm{~b}$ & $100.0 \pm 0.0 \mathrm{~b}$ \\
& 5.0 & $14.0 \pm 1.7 \mathrm{ab}$ & $80.0 \pm 3.3 \mathrm{~b}$ & $100.0 \pm 0.0 \mathrm{~b}$ & $100.0 \pm 0.0 \mathrm{~b}$ \\
& 10.0 & $22.5 \pm 3.6 \mathrm{c}$ & $98.2 \pm 2.2 \mathrm{c}$ & $100.0 \pm 0.0 \mathrm{~b}$ & $100.0 \pm 0.0 \mathrm{~b}$ \\
& 20.0 & $76.5 \pm 5.8 \mathrm{~d}$ & $100.0 \pm 0.0 \mathrm{c}$ & $100.0 \pm 0.0 \mathrm{~b}$ & $100.0 \pm 0.0 \mathrm{~b}$ \\
& 40.0 & $100.0 \pm 0.0 \mathrm{~d}$ & $100.0 \pm 0.0 \mathrm{c}$ & $100.0 \pm 0.0 \mathrm{~b}$ & $100.0 \pm 0.0 \mathrm{~b}$ \\
& 60.0 & $100.0 \pm 0.0 \mathrm{~d}$ & $100.0 \pm 0.0 \mathrm{c}$ & $100.0 \pm 0.0 \mathrm{~b}$ & $100.0 \pm 0.0 \mathrm{~b}$ \\
& 80.0 & $100.0 \pm 0.0 \mathrm{~d}$ & $100.0 \pm 0.0 \mathrm{c}$ & $100.0 \pm 0.0 \mathrm{~b}$ & $100.0 \pm 0.0 \mathrm{~b}$ \\
& 100.0 & $100.0 \pm 0.0 \mathrm{~d}$ & $100.0 \pm 0.0 \mathrm{c}$ & $100.0 \pm 0.0 \mathrm{~b}$ & $100.0 \pm 0.0 \mathrm{~b}$ \\
\hline OG-EO & 2.5 & $0.0 \pm 0.0 \mathrm{a}$ & $0.0 \pm 0.0 \mathrm{a}$ & $0.0 \pm 0.0 \mathrm{a}$ & $0.0 \pm 0.0 \mathrm{a}$ \\
& 5.0 & $0.0 \pm 0.0 \mathrm{a}$ & $80.3 \pm 1.4 \mathrm{~b}$ & $80.5 \pm 3.6 \mathrm{~b}$ & $88.2 \pm 4.4 \mathrm{~b}$ \\
& 10.0 & $0.0 \pm 0.0 \mathrm{a}$ & $86.2 \pm 3.6 \mathrm{~b}$ & $86.5 \pm 3.8 \mathrm{~b}$ & $88.2 \pm 4.2 \mathrm{~b}$ \\
& 20.0 & $96.1 \pm 3.5 \mathrm{~b}$ & $100.0 \pm 0.0 \mathrm{~b}$ & $100.0 \pm 0.0 \mathrm{~b}$ & $100.0 \pm 0.0 \mathrm{~b}$ \\
& 40.0 & $92.5 \pm 6.5 \mathrm{~b}$ & $98.0 \pm 4.4 \mathrm{~b}$ & $100.0 \pm 0.0 \mathrm{~b}$ & $100.0 \pm 0.0 \mathrm{~b}$ \\
& 60.0 & $92.5 \pm 3.5 \mathrm{~b}$ & $100.0 \pm 0.0 \mathrm{~b}$ & $100.0 \pm 0.0 \mathrm{~b}$ & $100.0 \pm 0.0 \mathrm{~b}$ \\
& 80.0 & $90.0 \pm 4.3 \mathrm{~b}$ & $100.0 \pm 0.0 \mathrm{~b}$ & $100.0 \pm 0.0 \mathrm{~b}$ & $100.0 \pm 0.0 \mathrm{~b}$ \\
& 100.0 & $90.0 \pm 4.3 \mathrm{~b}$ & $98.2 \pm 5.8 \mathrm{~b}$ & $100.0 \pm 0.0 \mathrm{~b}$ & $100.0 \pm 0.0 \mathrm{~b}$ \\
\hline ST-EO & 2.5 & $0.0 \pm 0.0 \mathrm{a}$ & $0.0 \pm 0.0 \mathrm{a}$ & $0.0 \pm 0.0 \mathrm{a}$ & $0.0 \pm 0.0 \mathrm{a}$ \\
& 5.0 & $0.0 \pm 0.0 \mathrm{a}$ & $10.3 \pm 0.9 \mathrm{a}$ & $18.2 \pm 1.4 \mathrm{a}$ & $48.3 \pm 3.1 \mathrm{~b}$ \\
& 10.0 & $0.0 \pm 0.0 \mathrm{a}$ & $6.2 \pm 1.1 \mathrm{a}$ & $20.2 \pm 0.7 \mathrm{a}$ & $48.3 \pm 3.3 \mathrm{~b}$ \\
& 20.0 & $16.3 \pm 6.8 \mathrm{abc}$ & $88.0 \pm 3.8 \mathrm{~b}$ & $94.5 \pm 7.1 \mathrm{~b}$ & $100.0 \pm 0.0 \mathrm{c}$ \\
& 40.0 & $8.2 \pm 3.4 \mathrm{ab}$ & $88.0 \pm 3.3 \mathrm{~b}$ & $96.5 \pm 5.6 \mathrm{~b}$ & $100.0 \pm 0.0 \mathrm{c}$ \\
& 60.0 & $30.0 \pm 2.1 \mathrm{c}$ & $96.0 \pm 2.9 \mathrm{bc}$ & $100.0 \pm 0.0 \mathrm{~b}$ & $100.0 \pm 0.0 \mathrm{c}$ \\
& 80.0 & $30.0 \pm 1.7 \mathrm{c}$ & $96.0 \pm 4.5 \mathrm{bc}$ & $100.0 \pm 0.0 \mathrm{~b}$ & $100.0 \pm 0.0 \mathrm{c}$ \\
& 100.0 & $24.6 \pm 3.3 \mathrm{bc}$ & $100.0 \pm 0.0 \mathrm{c}$ & $100.0 \pm 0.0 \mathrm{~b}$ & $100.0 \pm 0.0 \mathrm{c}$ \\
\hline
\end{tabular}

For each exposure period, the percentages with the same letters do not differ by the Tukey Test $(P>0.05)$. 


\section{Results and discussion}

The increasing need to eliminate pests from stored beans has raised interest in the fumigant toxicity of plant-derived EOs (Bett et al., 2016; Titouhi et al., 2017), which are excellent candidates for natural insecticides. We tested the target EOs at different concentrations and assayed their fumigant toxicities against Z. subfasciatus for $12,24,48$, and $72 \mathrm{~h}$. We also calculated the $\mathrm{LD}_{50}$ values for each $\mathrm{EO}$ at the respective treatment times.

CA-EO at $20.0 \mu \mathrm{L} / \mathrm{L}$ of air displayed $100 \%$ efficiency against Z. subfasciatus after $12 \mathrm{~h}$ (see Table 1 ). On the other hand, OG-EO and ST-EO at 20.0 and $100.0 \mu \mathrm{L} / \mathrm{L}$ of air, respectively, killed $100 \%$ of weevils after $24 \mathrm{~h}$. The negative control did not inhibit the weevils, whereas the positive control killed $100 \%$ of the insects at all the tested times.

Previous studies have demonstrated the C. ambrosioides EO fumigant effect against the weevils Callosobruchus maculatus F. (Coleoptera: Bruchidae) and Sitophilus zeamais Motschulsky (Coleoptera: Curculionidae); $24 \mathrm{~h} \mathrm{LD}_{50}$ values were 1.33 and $1.90 \mu \mathrm{L} / \mathrm{L}$ of air, respectively (Denloye et al., 2010). Investigation into the 0 . gratissimum EO insecticidal properties against $S$. zeamais provided $\mathrm{LD}_{50}$ of $37.9 \mu \mathrm{g} / \mathrm{mL}$ of air (Nguemtchouin et al., 2013). With respect to the EOs evaluated here, CA-EO displayed the lowest $24 \mathrm{~h} \mathrm{LD}_{50}$ value, $0.8 \mu \mathrm{L} / \mathrm{L}$ of air, against $Z$. subfasciatus, which demonstrated its high toxicity against the weevil (see Table 2). Concerning OG-EO, $24 \mathrm{~h} \mathrm{LD}_{50}$ was $1.2 \mu \mathrm{L} / \mathrm{L}$ of air. ST-EO afforded the

Table 2

Essential oil $\mathrm{LD}_{50}$ as determined by the fumigant activity assay.

\begin{tabular}{lllll}
\hline EO & E Exposure time & Slope $\pm S E$ & $\mathrm{LD}_{50} / \mathrm{CI}$ & $X^{2}$ \\
\hline CA-EO & $12 \mathrm{~h}$ & $5.2 \pm 1.1$ & $7.4(5.4-8.8)$ & 15.3 \\
& $24 \mathrm{~h}$ & $2.7 \pm 0.7$ & $0.8(0.4-1.2)$ & 8.8 \\
& $48 \mathrm{~h}$ & $*$ & $*$ & $*$ \\
& $72 \mathrm{~h}$ & $*$ & $*$ & $*$ \\
\hline OG-EO & $12 \mathrm{~h}$ & $2.5 \pm 0.2$ & $18.6(14.8-22.6)$ & 46.3 \\
& $24 \mathrm{~h}$ & $1.4 \pm 0.3$ & $1.2(0.2-2.8)$ & 38.1 \\
& $48 \mathrm{~h}$ & $1.6 \pm 0.5$ & $1.0(0.02-2.0)$ & 15.2 \\
& $72 \mathrm{~h}$ & $1.4 \pm 0.4$ & $0.8(0.02-1.8)$ & 19.8 \\
\hline ST-EO & $12 \mathrm{~h}$ & $1.4 \pm 0.3$ & $217.4(130.0-692.4)$ & 37.3 \\
& $24 \mathrm{~h}$ & $2.9 \pm 0.2$ & $14.8(11.8-18.0)$ & 56.4 \\
& $48 \mathrm{~h}$ & $3.8 \pm 0.4$ & $9.8(8.2-11.8)$ & 45.4 \\
& $72 \mathrm{~h}$ & $2.6 \pm 1.0$ & $5.6(4.4-7.0)$ & 32.8 \\
\hline
\end{tabular}

$\mathrm{LD}=$ Lethal dose $(\mu \mathrm{L} / \mathrm{L}$ of air $) ; \mathrm{CI}=$ confidence interval at $95 \%$ probability; $X^{2}=$ chisquare test. * Data are absent because the insects died within the first hour of experiment.

Table 3

CA-EO, OG-EO and ST-EO repelling activity against $Z$. subfasciatus.

\begin{tabular}{lllllll}
\hline EO & $\begin{array}{l}\text { Dose }(\mu \mathrm{L}) / \\
\text { Kg of beans }\end{array}$ & \multicolumn{2}{l}{$\mathrm{AI}^{\mathrm{NI}}{ }^{\mathrm{b}}$} & ${\text { Class } \mathrm{I}^{\mathrm{c}}}^{\mathrm{a}}$ & $\mathrm{C}^{\mathrm{d}}$ \\
\cline { 3 - 6 } & & Test & Control & & & \\
\hline CA-EO & 50 & 24 & 76 & $0.48 \pm 0.07$ & $0.23 ; 1.17$ & $\mathrm{R}$ \\
& 100 & 24 & 76 & $0.48 \pm 0.08$ & $0.32 ; 1.18$ & $\mathrm{R}$ \\
& 500 & 23 & 77 & $0.46 \pm 0.10$ & $0.36 ; 1.24$ & $\mathrm{R}$ \\
\hline OG-EO & 50 & 42 & 58 & $0.84 \pm 0.23$ & $0.46 ; 1.54$ & $\mathrm{~N}$ \\
& 100 & 43 & 57 & $0.58 \pm 0.19$ & $0.55 ; 1.45$ & $\mathrm{~N}$ \\
& 500 & 18 & 82 & $0.36 \pm 0.15$ & $0.24 ; 1.36$ & $\mathrm{R}$ \\
\hline ST-EO & 50 & 41 & 59 & $0.83 \pm 0.22$ & $0.49 ; 1.51$ & $\mathrm{~N}$ \\
& 100 & 36 & 64 & $0.69 \pm 0.15$ & $0.66 ; 1.34$ & $\mathrm{~N}$ \\
& 500 & 41 & 59 & $0.80 \pm 0.11$ & $0.75 ; 1.25$ & $\mathrm{~N}$ \\
\hline
\end{tabular}

\footnotetext{
a Percentage of attracted insects.

b Repellent index (Average \pm Average standard error).

c Classification index.

d Classification: $\mathrm{R}=$ repelling activity, $\mathrm{N}=$ neutral activity, $\mathrm{A}=$ attractive activity.
}

highest $24 \mathrm{~h} \mathrm{LD}_{50}: 14.8 \mu \mathrm{L} / \mathrm{L}$ of air. The aforementioned EOs proved to be promising sources of active compounds against $Z$. subfasciatus. CA-EO and OG-EO were the most active EOs and could be an interesting environmentally friendly alternative to eliminate $Z$. subfasciatus from stored beans. In all cases, the negative control (Tween 80 ) did not present toxicity, whereas the positive control killed $100 \%$ Z. subfasciatus.

The plant EOs tested here had excellent repellent action (see Table 3); i.e., they provided a vapor barrier that deterred the insects (Stella et al., 2010). Treatment of P. vulgaris grains with Corymbia citriodora (Hook.) K.D.Hill \& L.A.S.Johnson, Cymbopogon citratus (DC) Stapf. and Camellia oleifera C. Abel oils at $500 \mu \mathrm{L} / \mathrm{kg}$ of beans repelled Z. subfasciatus adults (França et al., 2012). The S. terebinthifolius repellent activity against Sitophilus zeamais was $2000 \mu \mathrm{L} / \mathrm{kg}$ of maize (Coitinho et al., 2010). The O. gratissimum L. EO (at $500,1000,1500$, and $2000 \mu \mathrm{L} / \mathrm{g}$ of grain) repellent effects were evaluated against Sitophilus oryzae (L.), Tribolium castaneum (Herbst), Oryzaephilus surinamensis (L.), Rhyzopertha dominica (F.), and Callosobruchus chinensis (L.) adults, to give 37.5\%-100\% repellent activity (Ogendo et al., 2008).

As for our repellent activity tests, CA-EO was the most promising because it was active at the three assayed doses. OG-EO was only active at $500 \mu \mathrm{L} / \mathrm{kg}$ of beans, whereas ST-EO was inactive (neutral activity for the three tested doses). No repellent activity emerged for untreated beans (negative control). The repellent effects depended on the applied dose and on the tested EO.

In summary, all the evaluated EOs killed $100 \%$ Z. subfasciatus, which is one of the main pests causing stored grain losses. CA-EO and $\mathrm{OG}$-EO presented the lowest $\mathrm{LD}_{50}$ values and were the most active in the repellent activity tests. Although further studies are necessary to understand which EO constituents underlie the EO insecticidal activity, the remarkable CA-EO insecticidal action opens up possibilities for a safer, environmentally friendly, and economically viable option to conserve stored beans and to manage pests according to international biosafety regulations.

\section{Acknowledgements}

The authors thank the Brazilian foundations FAPESP (Process 2007/54241-8) and CNPq (Process 303892/2016-1) for financial support and fellowships.

\section{References}

Abbott, W.A., 1985. A method for computing the effectiveness of an insecticide J. Am. Mosq. Control Assoc. 3, 302-303.

Alonso-Amelot, M.E., Avila-Núñez, J.L., 2011. Comparison of seven methods for stored cereal losses to insects for their application in rural conditions. J. Stored Prod. Res. 47, 82-87.

Babu, R.M., Sajeena, A., Seetharaman, K., Reddy, M.S., 2003. Advances in genetically engineered (transgenic) plants in pest management - an overview. Crop Prot. 22, 1071-1086.

Bakkali, F., Averbeck, S., Averbeck, D., Idaomar, M., 2008. Biological effects of essential oils - a review. Food Chem. Toxicol. 46, 446-475.

Baldin, E.L.L., Lara, F.M., 2008. Resistance of stored bean varieties to Acanthoscelides obtectus (Coleoptera: Bruchidae). Insect Sci. 15, 317-326.

Bett, P.K., Deng, A.L., Ogendo, J.O., Kariuki, S.T., Kamatenesi-Mugisha, M. Mihale, J.M., Torto, B., 2016. Chemical composition of Cupressus lusitanica and Eucalyptus saligna leaf essential oils and bioactivity against major insect pests of stored food grains. Ind. Crops Prod. 82, 51-62.

Coitinho, R.L.B. de C., Oliveira, J.V., Júnior, M.G.C.G., Câmara, C.A.G., 2010. Persistence of essential oils in stored maize submitted to infestation of maize weevil. Ciênc. Rural 40, 1492-1496.

Costa, J.T. da, Forim, M.R., Costa, E.S., Souza, J.R. de, Mondego, J.M., Junior, A.L.B. 2014. Effects of different formulations of neem oil-based products on control Zabrotes subfasciatus (Boheman, 1833) (Coleoptera: Bruchidae) on beans. J. Stored Prod. Res. 56, 49-53.

Denloye, A.A., Makanjuola, W.A., Teslim, O.K., Alafia, O.A., Kasali, A.A. Eshilokun, A.O., 2010. Toxicity of Chenopodium Ambrosioides L. (Chenopodiaceae) products from Nigeria against three storage insects. J. Plant Prot. Res. 50 379-384. 
Enan, E., 2001. Insecticidal activity of essential oils: octopaminergic sites of action. Comp. Biochem. Physiol. Part C 130, 325-337.

Enan, E.E., 2005. Molecular and pharmacological analysis of an octopamine receptor from american cockroach and fruit fly in response to plant essential oils. Arch. Insect Biochem. Physiol. 59, 161-171.

França, S.M. de, Oliveira, J.V. de, Esteves Filho, A.B., Oliveira, C.M. de, 2012. Toxicity and repellency of essential oils to Zabrotes subfasciatus (Boheman) (Coleoptera, Chrysomelidae, Bruchinae) in Phaseolus vulgaris L. Acta Amaz. 42, 381-386.

Jumbo, L.O.V., Faroni, L.R.A., Oliveira, E.E., Pimentel, M.A., Silva, G.N., 2014. Potentia use of clove and cinnamon essential oils to control the bean weevil, Acanthoscelides obtectus Say, in small storage units. Ind. Crop. Prod. 56, 27-34.

Lagarda-Diaz, I., Guzman-Partida, A.M., Urbano-Hernandez, G., OrtegaNieblas, M.M., Robles-Burgueño, M.R., Winzerling, J., Vazquez-Moreno, L., 2009. Insecticidal action of PF2 lectin from Olneya tesota (Palo Fierro) against Zabrotes subfasciatus larvae and midgut glycoconjugate binding. J. Agric. Food Chem. 57, 689-694.

Lin, H., Kogan, M., Fischer, D., 1990. Induced resistance in soybean to the Mexican bean beetle (Coleoptera: Coccinellidae): comparisons of inducing factors. Environ. Entomol. 19, 1852-1857.

López, M.D., Pascual-Villalobos, M.J., 2010. Mode of inhibition of acetylcholines terase by monoterpenoids and implications for pest control. Ind. Crops Prod. 31, 284-288.

Madrid, F.J., White, N.D.G., Loschiavo, S.R., 1990. Insects in stored cereals, and their association with farming practices in southern Manitoba. Can. Entomol. 122 $515-523$.

Moshi, A.P., Matoju, I., 2017. The status of research on and application of biopesticides in Tanzania. Review. Crop Prot. 92, 16-28.

Nguemtchouin, M.G.M., Ngassoum, M.B., Chalier, P. Kamga, R., Ngamo, L.S.T. Cretin, M., 2013. Ocimum gratissimum essential oil and modified montmorillonite clay, a means of controlling insect pests in stored products. J. Stored Prod. Res. 52, 57-62.

Ogendo, J.O., Kostyukovsky, M., Ravid, U., Matasyoh, J.C., Deng, A.L., Omolo, E.O., Kariuki, S.T., Shaaya, E., 2008. Bioactivity of Ocimum gratissimum L. oil and two of its constituents against five insect pests attacking stored food products. J. Stored Prod. Res. 44, 328-334.

Priestley, C.M., Williamson, E.M., Wafford, K.A., Sattelle, D.B., 2003. Thymol, a constituent of thyme essential oil, is a positive allosteric modulator of human GABAA receptors and a homo-oligomeric GABA receptor from Drosophila melanogaster. Br. J. Pharmacol. 140, 1363-1372.

Procópio, S. de O., Vendramim, J.D., Júnior, J.I.R., Santos, J.B. dos, 2003. Bioatividade de diversos pós de origem vegetal em relação a Sitophilus zeamais Mots. (Coleoptera: Curculionidae). Ciência e Agrotecnologia 27.

SAS Institute, S., 2001. SAS/STAT User's Guide Version 8.1.

Stella, L.N., Olivero-verbel, J., Stashenko, E., 2010. Repellent activity of essential oils: a review. Bioresour. Technol. 101, 372-378.

Titouhi, F. Amri, M. Messaoud, C., Haouel, S. Youssfi, S, Cherif, A., Jemaa, J.M. Ben, 2017. Protective effects of three Artemisia essential oils against Callosobruchus maculatus and Bruchus rufimanus (Coleoptera: Chrysomelidae) and the extended side-effects on their natural enemies. J. Stored Prod. Res. 72, 11-20.

Winer, B.J., Brown, D.R., Michels, K.M., 1991. Statistical Principles in Experimental Design. McGraw-Hill, New York. 